\title{
Expression of serotonin receptors in human lower esophageal sphincter
}

\author{
HE-FEI LI, JUN-FENG LIU, KE ZHANG and YONG FENG \\ Department of Thoracic Surgery, Fourth Hospital of Hebei Medical University, Shijiazhuang, Hebei 050011, P.R. China
}

Received March 10, 2014; Accepted October 8, 2014

DOI: $10.3892 /$ etm.2014.2050

\begin{abstract}
Serotonin (5-HT) is a neurotransmitter and vasoactive amine that is involved in the regulation of a large number of physiological functions. The wide variety of 5-HT-mediated functions is due to the existence of different classes of serotonergic receptors in the mammalian gastrointestinal tract and nervous system. The aim of this study was to explore the expression of multiple types of 5-HT receptor $\left(5-\mathrm{HT}_{1 \mathrm{~A}} \mathrm{R}, 5-\mathrm{HT}_{2 \mathrm{~A}} \mathrm{R}\right.$, 5- $\mathrm{HT}_{3 \mathrm{~A}} \mathrm{R}, 5-\mathrm{HT}_{4} \mathrm{R}, 5-\mathrm{HT}_{5 \mathrm{~A}} \mathrm{R}, 5-\mathrm{HT}_{6} \mathrm{R}$ and 5-HT $\mathrm{R}$ ) in sling and clasp fibers from the human lower esophageal sphincter (LES). Muscle strips of sling and clasp fibers from the LES were obtained from patients undergoing esophagogastrectomy, and circular muscle strips from the esophagus and stomach were used as controls. Reverse transcription-polymerase chain reaction (RT-PCR), quantitative PCR and western blotting were used to investigate the expression of the various 5-HT receptor types. Messenger RNA for all seven 5-HT receptor types was identified in the sling and clasp fibers of the LES. At the mRNA level, the expression levels were highest for $5-\mathrm{HT}_{3 \mathrm{~A}} \mathrm{R}$ and $5-\mathrm{HT}_{4} \mathrm{R}$, and lowest for $5-\mathrm{HT}_{5 \mathrm{~A}} \mathrm{R}, 5-\mathrm{HT}_{6} \mathrm{R}$ and $5-\mathrm{HT}_{7} \mathrm{R}$. At the protein level, the expression levels were highest for $5-\mathrm{HT}_{3 \mathrm{~A}} \mathrm{R}$ and $5-\mathrm{HT}_{4} \mathrm{R}$, followed by $5-\mathrm{HT}_{1 \mathrm{~A}} \mathrm{R}$ and $5-\mathrm{HT}_{2 \mathrm{~A}} \mathrm{R}$; $5-\mathrm{HT}_{7} \mathrm{R}$ was also detected at a low level. The expression of $5-\mathrm{HT}_{5 \mathrm{~A}} \mathrm{R}$ and $5-\mathrm{HT}_{6} \mathrm{R}$ proteins was not confirmed. The results indicate that a variety of 5-HT receptor types can be detected in the human LES and probably contribute to LES function.
\end{abstract}

\section{Introduction}

Serotonin (5-hydroxytryptamine, 5-HT) has important biological functions that are mediated via 5-HT receptors. Seven families of 5-HT receptors, designated from 5-HT1 to 5-HT7, are currently recognized and more than sixteen subtypes have been identified in humans. With the exception of the 5-HT3

Correspondence to: Professor Jun-Feng Liu, Department of Thoracic Surgery, Fourth Hospital of Hebei Medical University, 12 Jiankang Road, Shijiazhuang, Hebei 050011, P.R. China E-mail: surgeonliujf@sina.com

Key words: serotonin receptors, human, lower esophageal sphincter, sling fibers, clasp fibers receptor, the receptors are members of the seven transmembrane domain $\mathrm{G}$ protein-coupled receptor family, while the 5-HT3 receptor is a ligand-gated ion channel belonging to the Cys-loop superfamily of pentameric proteins (1).

The majority of 5-HT in the body is produced by enterochromaffin cells in the gut. 5-HT receptors are widely distributed in the gastrointestinal mucosa and muscle layers, and play an important role in the functional mediation of the gastrointestinal tract (2). It has been found that 5-HT receptors are widely expressed in the gastrointestinal tracts of mammals, such as the rat and opossum (3). However, there is little information available concerning 5-HT receptor expression in the human lower esophageal sphincter (LES). The LES is an important physiological structure at the esophagogastric junction. Abnormalities in the LES are closely associated with dysfunction in gastrointestinal motility disorders such as achalasia and gastroesophageal reflux disease (GERD) (4).

The objective of the present study was to detect 5-HT receptors in the human LES, in particular, within the clasp and sling fibers of the LES. Following the identification of their expression patterns, the role of the 5-HT receptors in the modulation of human LES function was further investigated.

\section{Materials and methods}

Patients and tissue retrieval. The experimental protocol has been approved by the Research Ethics Committee of the Fourth Hospital of Hebei Medical University (Shijiazhuang, China). Written informed consent was obtained from the patients. Muscle strips were collected from 28 patients who underwent esophagectomy for mid-third esophageal carcinoma in the Department of Thoracic Surgery at this hospital from March 2012 to August 2012. There were 16 males and 12 females, with an average age of 58 years (range, 50 to 67 years). Patients with a history of GERD, achalasia, scleroderma, or other diseases associated with a disorder of the LES were excluded from the study. Each specimen was resected en bloc in the operating room, and the fresh specimen was placed immediately in ice-cold Krebs solution. The Krebs solution had the following composition (in $\mathrm{mM}$ ): sodium, 143.0; potassium, 5.0; calcium, 2.5; magnesium, 1.2; chloride, 128.0; phosphate, 2.2; bicarbonate, 24.9; sulfate, 1.2; and glucose, 10.0. Specimens were not included in this study if any segment that was required for study contained a macroscopically visible tumor. 
Table I. Primer sequences and expected product sizes for RT-PCR.

\begin{tabular}{|c|c|c|}
\hline Gene & Primer pair sequence (sense/antisense) & Product size $(b p)$ \\
\hline $5-\mathrm{HT}_{1 \mathrm{~A}} \mathrm{R}$ & $\begin{array}{l}\text { 5'-GGCGGCAACACTACTGGTAT-3' } \\
\text { 5'-AGCCAAGTGAGCGAGATGAG -3' }\end{array}$ & 422 \\
\hline $5-\mathrm{HT}_{2 \mathrm{~A}} \mathrm{R}$ & $\begin{array}{l}\text { 5'-ACTCGCCGATGATAACTTTGTCCT-3' } \\
\text { 5'-TGACGGCCATGATGTTTGTGAT-3' }\end{array}$ & 359 \\
\hline $5-\mathrm{HT}_{3 \mathrm{~A}} \mathrm{R}$ & $\begin{array}{l}\text { 5'-CCGGCGGCCCCTCTTCTAT-3' } \\
\text { 5'-GCAAAGTAGCCAGGCGATTCTCT-3' }\end{array}$ & $448 / 352$ \\
\hline $5-\mathrm{HT}_{4} \mathrm{R}$ & $\begin{array}{l}\text { 5'-GGCCTTCTACATCCCATTTCTCCT-3' } \\
\text { 5'-CTTCGGTAGCGCTCATCATCACA-3' }\end{array}$ & 411 \\
\hline $5-\mathrm{HT}_{5 \mathrm{~A}} \mathrm{R}$ & $\begin{array}{l}\text { 5'-CCCTTCTGCAAGTACCCCAG-3' } \\
\text { 5'-ATGACGTTGGAGACGCACTT-3' }\end{array}$ & 522 \\
\hline $5-\mathrm{HT}_{6} \mathrm{R}$ & $\begin{array}{l}\text { 5'-CCGCCGGCCATGCTGAACG-3' } \\
\text { 5'-GCCCGACGCCACAAGGACAAAAG-3' }\end{array}$ & 342 \\
\hline $5-\mathrm{HT}_{7} \mathrm{R}$ & $\begin{array}{l}\text { 5'-GCGCTGGCCGACCTCTC-3' } \\
\text { 5'-TCTTCCTGGCAGCCTTGTAAATCT-3' }\end{array}$ & 436 \\
\hline$\beta$-actin & $\begin{array}{l}\text { 5'-GTGGGGCGCCCCAGGCACCA-3' } \\
\text { 5'-CTCCTTAATGTCACGCACGATTTC-3' }\end{array}$ & 540 \\
\hline
\end{tabular}

RT-PCR, reverse transcription-polymerase chain reaction; 5-HT, serotonin; R, receptor.

In the laboratory, the fresh specimens of the gastroesophageal junction were opened along the long axis of the esophagus and the greater curvature of the stomach. Specimens were pinned to a wax plate in the presence of Krebs solution at $37^{\circ} \mathrm{C}$ to maintain its approximate in situ dimensions, with a continuous supply of mixed gas of $95 \% \mathrm{O}_{2}$ and $5 \% \mathrm{CO}_{2}$. The mucosa and submucosa were then removed by dissection.

The sling and clasp fibers were identified as thickened bands of circular oriented smooth muscle in the gastric cardia, adjacent to the greater and lesser curvature of the stomach, respectively. The sling and clasp muscle strips were prepared using a previously described method $(5,6)$. In addition, circular muscle fibers from the esophagus above the LES, and circular muscle fibers from the gastric fundus below the LES, were dissected for use as control specimens. These circular muscle strips were obtained $3 \mathrm{~cm}$ proximal and distal to the gastroesophageal junction. All specimens were removed carefully to ensure that the myenteric plexus and the longitudinal muscle in the wall of the esophagus and stomach were excluded. The dissected muscle strips from the four parts were frozen in liquid nitrogen and stored at $-80^{\circ} \mathrm{C}$ for subsequent RNA extraction.

RNA isolation and reverse transcription-polymerase chain reaction (RT-PCR) for 5-HT receptor analysis. Tissue was homogenized in TRIzol reagent (Invitrogen Life Technologies, Carlsbad, CA, USA) at a ratio of $100 \mathrm{mg}$ tissue to $1 \mathrm{ml}$ TRIzol, and then centrifuged at 12,000 x g for $5 \mathrm{~min}$. Total RNA was extracted by acid guanidinium thiocyanate-phenol-chloroform extraction. The quality of the RNA was verified by agarose gel electrophoresis using ethidium bromide staining. First-strand cDNA synthesis (reaction volume, $20 \mu \mathrm{l}$ ) using 2 mg RNA was performed by $\mathrm{RT}$ reaction in the presence of RevertAid
Moloney Murine Leukemia Virus (M-MuLV) reverse transcriptase (Fermentas, Thermo Fisher Scientific, Waltham, MA, USA). RT was conducted with $0.5 \mathrm{mg}$ oligo(dT) $)_{18}$, using diethypyrocarbonate (DEPC)-treated water to achieve a volume of $11 \mu \mathrm{l}$, and the reaction mixture was incubated at $70^{\circ} \mathrm{C}$ for $5 \mathrm{~min}$, prior to being chilled on ice. Next, $4 \mu \mathrm{l}$ $5 \mathrm{X}$ reaction buffer (Fermentas), $2 \mu 110 \mathrm{mM} 4 \mathrm{dNTP}$ mix and 20 units RNasin (both from Fermentas) were added, using DEPC-treated water to provide a reaction volume of $19 \mu 1$, and the mixture was incubated at $37^{\circ} \mathrm{C}$ for $5 \mathrm{~min}$. Finally, 200 units (1 $\mu \mathrm{l})$ RevertAid M-MuLV reverse transcriptase was added, and the reaction mixture was incubated at $37^{\circ} \mathrm{C}$ for $50 \mathrm{~min}$, before the reaction was stopped and held at $70^{\circ} \mathrm{C}$ for $15 \mathrm{~min}$.

PCR amplification of the cDNA was performed using primers designed specifically to match the 5-HT receptor mRNA (primers listed in Table I). In each PCR reaction, $2 \mu 1$ cDNA reaction mixture was used. PCR was performed in a 20- $\mu 1$ reaction volume. The amplification conditions were: 5 min initial denaturation at $95^{\circ} \mathrm{C}$, then 36 cycles of $95^{\circ} \mathrm{C}$ for $35 \mathrm{sec}, 60^{\circ} \mathrm{C}$ for $35 \mathrm{sec}$ and $72^{\circ} \mathrm{C}$ for $45 \mathrm{sec}$ followed by $72^{\circ} \mathrm{C}$ for $5 \mathrm{~min}$. A negative control in which all the components of the reaction were added, except the cDNA template was tested in parallel with each sample to identify any risk of false positive results. The amplified products were electrophoresed on a $1.5 \%$ agarose gel and PCR products were determined using the Gel-Pro gel image analysis system (Media Cybernetics, Silver Spring, Maryland, USA). Densitometry for analysis of the PCR product bands was conducted by the imaging software. The relative expression level of each gene was normalized by the value of $\beta$-actin. The amplified products were analyzed by electrophoresis on $1.5 \%$ agarose gels and visualized by ethidium bromide staining, with images captured by photography under a UV transilluminator. The integrated optical 
density (IOD) of the gel was calculated with Gel-Pro software (Media Cybernetics). The relative expression level of the mRNA of each 5-HT receptor type was normalized by the value of $\beta$-actin.

Quantification by quantitative PCR ( $P P C R)$. The qPCR experiments were conducted using an Applied Biosystem 7500 Real-Time PCR System (Applied Biosystems, Foster City, CA, USA) and data were analyzed with ABI 7500 (version 2.0.6) software. All oligonucleotide primers for qPCR were designed using Primer 3 software (http://frodo.wi.mit.edu/cgi-bin/ primer3/primer3www.cgi) and synthesized by Invitrogen Life Technologies. The diluted cDNA ( $1 \mu 1$ from each sample) was used as PCR template. The reaction composition contained: $1 \mu \mathrm{l}$ diluted cDNA; $12.5 \mu \mathrm{l}$ 2X TransStart Top Green qPCR SuperMix (TransGen Biotech, Beijing, China.), $10 \mu \mathrm{ldd} \mathrm{H}_{2} \mathrm{O}$, $0.5 \mu \mathrm{l}$ forward primer and $0.5 \mu \mathrm{l}$ reverse primer, and $0.5 \mu \mathrm{l}$ Passive Reference Dye (TransGen Biotech) in a final volume of $25 \mu \mathrm{l}$. The cDNA was amplified by one cycle at $94^{\circ} \mathrm{C}$ for $30 \mathrm{sec}$, followed by 42 cycles of $95^{\circ} \mathrm{C}$ for $5 \mathrm{sec}, 60^{\circ} \mathrm{C}$ for $34 \mathrm{sec}$ and melt curve analysis. Reactions were performed in triplicate according to the manufacturers' instructions (TransGen Biotech). Melting point and melting curve analyses were undertaken on each set of reactions to confirm that only a single product was produced. No primer-dimers were detected by melting point analysis and this was confirmed in preliminary runs with gel electrophoresis. The expression level of the target gene was calculated by the $2^{-\Delta \Delta \mathrm{Ct}}$ method (7). The relative expression of target gene mRNA was indexed to the reference gene $\beta$-actin using the formula: $10,000 \times 2^{\Delta \mathrm{Ct}}$, in which $\Delta \mathrm{Ct}=\mathrm{Ct}_{\beta \text {-actin }}-\mathrm{Ct}_{\text {target gene }}$.

Western blot analysis of 5-HT receptors. Total proteins were extracted from the muscle strips using a protein extraction kit (Solarbio, Beijing, China). Protein concentration was determined using a colorimetric bicinchoninic acid (BCA) protein assay reagent (Multisciences, Hangzhou, China). Following denaturation at $100^{\circ} \mathrm{C}$ for $10 \mathrm{~min}$, aliquots of protein samples $(30 \mu \mathrm{g})$ were separated by electrophoresis on SDS-polyacrylamide gel $10 \%$ separation gel and $4 \%$ pycnotic gel, separated at $150 \mathrm{~V}$ for $1 \mathrm{~h}$, and transferred onto a polyvinylidene difluoride (PVDF) membrane, which was then blocked for $1 \mathrm{~h}$ with $5 \%$ non-fat milk in Tris-buffered saline with Tween 20 (TBST) at room temperature, and incubated with an anti-human, polyclonal primary antibody (dilutions: rabbit anti-5 $\mathrm{HT}_{1 \mathrm{~A}} \mathrm{R}, 1: 300$; rabbit anti-5 $\mathrm{HT}_{2 \mathrm{~A}} \mathrm{R}$, 1:400; rabbit anti-5 $\mathrm{HT}_{3 \mathrm{~A}} \mathrm{R}, 1: 500$; rabbit anti-5 $\mathrm{HT}_{4} \mathrm{R}, 1: 500$; rabbit anti-5 $\mathrm{HT}_{5 \mathrm{~A}} \mathrm{R}, 1: 300$; rabbit anti-5 $\mathrm{HT}_{6} \mathrm{R}, 1: 300$; rabbit anti-5 $\mathrm{HT}_{7} \mathrm{R}, 1: 300 ; 1: 10,000$ for the rabbit anti- $\beta$-actin; Abcam Trading, Shanghai, China) at $4^{\circ} \mathrm{C}$ overnight. After washing three times with TBST at room temperature for $30 \mathrm{~min}$ in total, the membrane was incubated with a goat anti-rabbit IgG polyclonal secondary antibody $(1: 2,000$, anti-rabbit IgG; Abcam Trading) for $1 \mathrm{~h}$. After three washes with TBST, the membrane was analyzed using an infrared fluorescence imaging instrument (Odyssey Infrared Imaging System, American LI-COR, Lincoln, Nebraska, USA). The IOD value was calculated by the Gel-Pro software and the relative expression level of each protein was normalized by the value of $\beta$-actin.

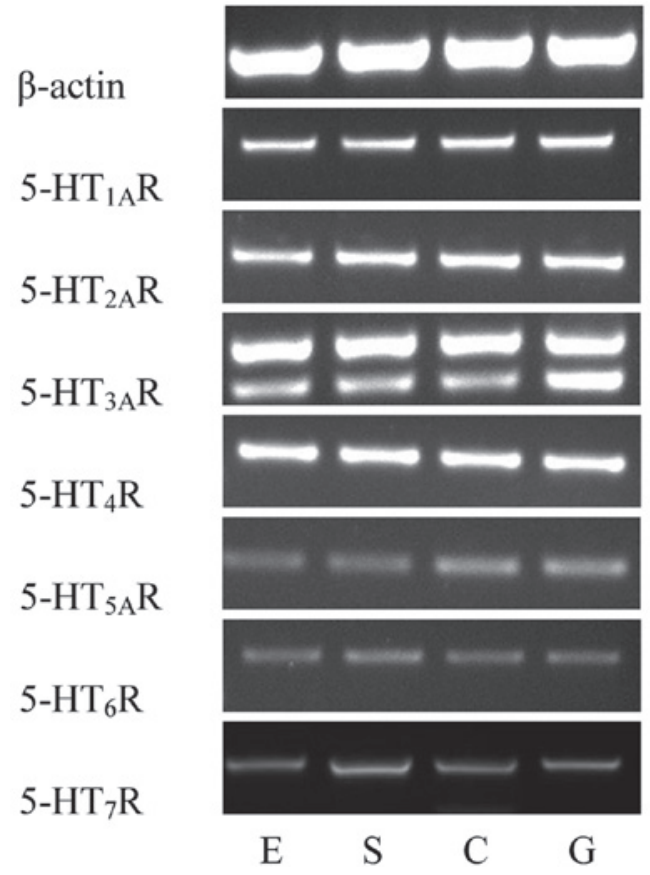

Figure 1. mRNA expression of 5-HT receptors in the sling and clasp fibers of the LES and circular muscle strips from the esophagus and stomach. A representative example of the RT-PCR products specific for each 5-HT receptor mRNA is shown. 5-HT, serotonin; LES, lower esophageal sphincter; RT-PCR, reverse transcription-polymerase chain reaction; E, circular muscle strip of esophagus; S, sling fibers; C, clasp fibers; G, stomach.

Statistical analysis. Results are expressed as the mean \pm standard deviation (SD). SAS software, version 9.2 (SAS Institute Inc., Cary, NC, USA) was used to conduct the statistical analysis. Differences in the mRNA and protein expression levels were analyzed with one-way analysis of variance, and the Student-Newman-Keuls multiple range (SNK-q) test was used to evaluate comparisons within groups. $\mathrm{P}<0.05$ was considered to indicate a statistically significant difference.

\section{Results}

Characterization of $m R N A$ encoding 5-HT receptors. Using RT-PCR, the mRNA expression levels of seven 5-HT receptors in the human LES were determined. Distinct bands of the expected sizes were detected for each of the seven 5-HT receptor mRNAs and their levels of expression appeared to differ. Similar results were obtained in all PCR assays performed on mRNA extracted from the 28 patients. The primer pairs designed to recognize the $5-\mathrm{HT}_{3 \mathrm{~A}} \mathrm{R}$ and $5-\mathrm{HT}_{4} \mathrm{R}$ mRNA generated strong bands, indicating high expression levels of the $5-\mathrm{HT}_{3 \mathrm{~A}} \mathrm{R}$ and $5-\mathrm{HT}_{4} \mathrm{R}$ mRNA. The 5-HT ${ }_{1 \mathrm{~A}} \mathrm{R}$ and 5- $\mathrm{HT}_{2 \mathrm{~A}} \mathrm{R}$ mRNA also generated comparatively strong bands. However, the primer pairs for the $5-\mathrm{HT}_{7} \mathrm{R}, 5-\mathrm{HT}_{5 \mathrm{~A}} \mathrm{R}$ and $5-\mathrm{HT}_{6} \mathrm{R}$ mRNA produced relatively weak bands (Fig. 1).

Quantification of 5-HT receptor $m R N A$ expression. To compare the expression levels of the seven different 5-HT receptor mRNAs, qPCR was performed. Significant differences were identified when the mRNA expression levels of the 5-HT receptors were compared in the same muscle strip ( $\mathrm{F}, 78.281 ; \mathrm{P}=0.000)$. The rank order of expression was as follows: $5-\mathrm{HT}_{3 \mathrm{~A}} \mathrm{R}=5-\mathrm{HT}_{4} \mathrm{R}>5-\mathrm{HT}_{1 \mathrm{~A}} \mathrm{R}=5-\mathrm{HT}_{2 \mathrm{~A}} \mathrm{R}$ 


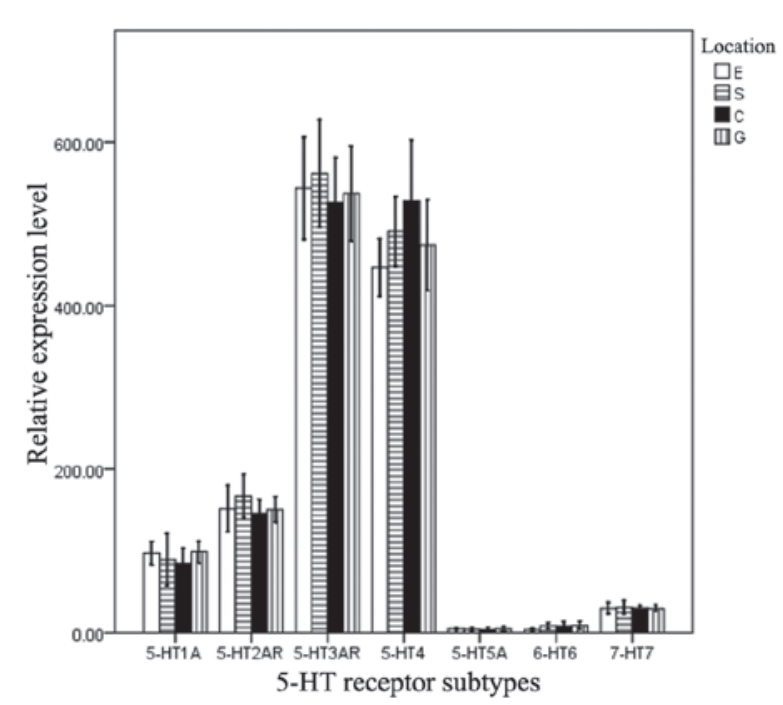

Figure 2. Quantitative determination of the mRNA expression levels of various 5-HT receptors in the sling and clasp fibers of the LES and circular muscle strips from the esophagus and stomach. Bar chart showing the relative mRNA expression levels of the various 5-HT receptors normalized against $\beta$-actin. There were significant differences between the 5-HT receptor subtypes in the same muscle strip $(\mathrm{P}<0.05)$, but no significant differences for each subtype across various muscle strips ( $\mathrm{P}>0.05)$. 5-HT, serotonin; LES, lower esophageal sphincter; IOD, integrated optical density; E, circular muscle strips of esophagus; S, sling fibers; C, clasp fibers; G, stomach.

$>5-\mathrm{HT}_{5 \mathrm{~A}} \mathrm{R}=5-\mathrm{HT}_{6} \mathrm{R}=5-\mathrm{HT}_{7} \mathrm{R}$. However, no significant difference was observed in the mRNA expression levels of the 5-HT receptors among the four types of muscle strip (F, 0.232; $\mathrm{P}=0.731$; Fig. 2).

Expression of 5-HT receptor proteins. With the exception of $5-\mathrm{HT}_{5 \mathrm{~A}} \mathrm{R}$ and $5-\mathrm{HT}_{6} \mathrm{R}$ proteins, the other five receptors were identified. Significant differences in the IOD values for the different 5-HT receptors in the same muscle strip were observed (F, 657.357; $\mathrm{P}=0.000)$. The rank order of the IOD values was as follows: $5-\mathrm{HT}_{3 \mathrm{~A}} \mathrm{R}=5-\mathrm{HT}_{4} \mathrm{R}>5-\mathrm{HT}_{1 \mathrm{~A}} \mathrm{R}=$ $5-\mathrm{HT}_{2 \mathrm{~A}} \mathrm{R}>5-\mathrm{HT}_{7} \mathrm{R}$. No significant differences in IOD values were identified among the four type of muscle strip ( $F, 0.194$; $\mathrm{P}=0.801$; Fig. 3).

\section{Discussion}

Serotonin (5-HT), as a predominant neurotransmitter, controls a variety of functions, including locomotor activity, cognition, emotion, food intake and endocrine regulation, via effects on 5-HT receptors. Currently, seven 5-HT receptors and more than sixteen 5-HT receptor subtypes have been identified as members of the $\mathrm{G}$ protein-coupled receptor or ligand-gated ion channel families. More specifically, these are the receptor subtypes of 5-HT1A, 5-HT1B, 5-HT1C, 5-HT1D, 5-HT1E, 5-HT1F, 5-HT2A, 5-HT2B, 5-Н 2C, 5-НT3А, 5-НТ3В, 5-НT4, 5-НT5А, 5-НТ5В, 5-HT6 and 5-HT7, of which the 5-HT7 receptor is divided into 5-HT7(a), 5-HT7(b) and 5-HT7(c) in humans. The 5-HT receptors are widely distributed in the central and peripheral nervous system, cardiovascular system and gastrointestinal tract in mammals, and have been shown to play significant physiological roles (8-10). Various esophageal motility
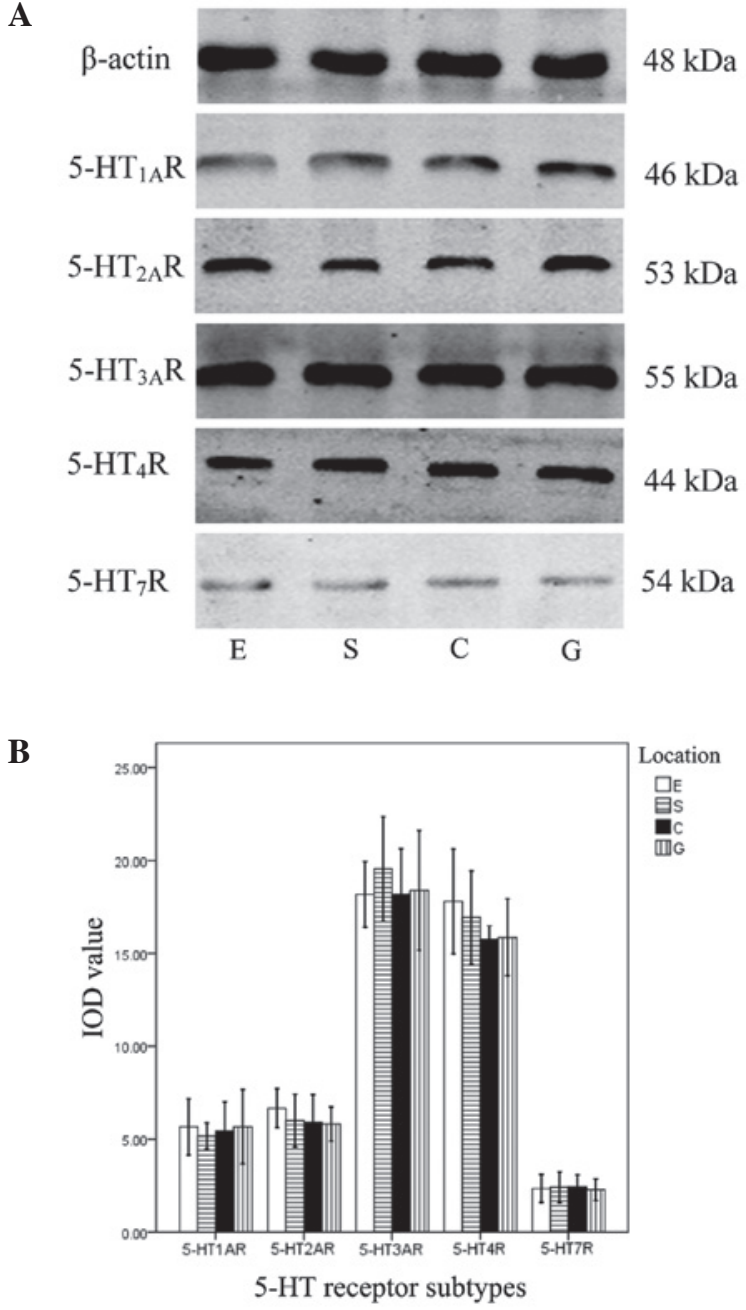

Figure 3. Expression of 5-HT receptor subtypes determined by western blot analysis in the sling and clasp fibers of the LES and circular muscle strips of the esophagus and stomach. (A) Bands of five 5-HT receptor subtypes in E, S, C and G were identified by western blotting. (B) IOD values of the bands. There were significant differences between the 5-HT subtypes in the same muscle strip $(\mathrm{P}<0.05)$, but no significant differences were identified in a single subtype between the four types of muscle strip $(\mathrm{P}>0.05)$. 5-HT, serotonin; LES, lower esophageal sphincter; IOD, integrated optical density; E, circular muscle strips of esophagus; S, sling fibers; C, clasp fibers; G, stomach.

disorders, such as achalasia, diffuse esophageal spasm and nutcracker esophagus, are associated with motor dysfunction of the LES (11). The regulatory mechanism of the LES involves various receptors (12), neurotransmitters and signal transduction pathways., including CCK, muscarinic and dopamine receptors $(5,6,13)$.

5-HT receptors are widely distributed in smooth muscle in various parts of the body, including the gastrointestinal tract, where they control aspects of gastrointestinal motility and secretion (14). 5-HT and serotonergic agonists and antagonists have been found to exert pharmacological effects on various regions of the gut. For example, $5-\mathrm{HT}_{3}$ receptor antagonists have antiemetic activity and $5-\mathrm{HT}_{4}$ receptor agonists are used to promote gastrointestinal peristalsis in the clinic $(15,16)$. Previous studies have evaluated the distribution of 5-HT receptors in the gastrointestinal tract. Mader et al (17) found that 5-HT $\mathrm{H}_{4}$ receptor mRNA expression 
was present throughout the gastrointestinal tract in humans and primates, which supports findings that $5-\mathrm{HT}_{4}$ receptors exhibit multiple effects in the gastrointestinal system. Champaneria et al (18) identified the expression of the $5-\mathrm{HT}_{3}$ receptor in rat gut. Irving et al (19) evaluated $5-\mathrm{HT}_{3}, 5-\mathrm{HT}_{4}$ and $5-\mathrm{HT}_{7}$ receptor expression and compared $5-\mathrm{HT}_{4}$ and $5-\mathrm{HT}_{7}$ receptor function in the circular muscle of the human colon. In addition, the 5- $\mathrm{HT}_{1 \mathrm{~A}}$ receptor was identified in guinea pig and human intestine by Wang et al (20). These findings prompt the hypothesis that 5-HT receptors are located throughout the gastrointestinal tract. However, prior to the present study, little information was available concerning the distribution of 5-HT receptors in the LES. The present study was designed to determine whether 5-HT receptors exist in the region of the human LES. The LES is a complex structure comprising clasp and sling fiber muscle strips in the gastric cardia, and circular muscle fibers in the distal end of the esophagus immediately above the gastroesophageal junction. In the present study, the clasp and sling fiber muscle strip component of the LES was investigated. 5- $\mathrm{HT}_{5}$ and $5-\mathrm{HT}_{6}$ receptors mainly exist in the central nervous system and are associated with memory, mood, pain and cognition (21-25). The gastrointestinal tract is known to express $5-\mathrm{HT}_{1}$, $5-\mathrm{HT}_{2}, 5-\mathrm{HT}_{3}, 5-\mathrm{HT}_{4}$ and $5-\mathrm{HT}_{7}$ receptors, which regulate the function of gastrointestinal tract. The 5- $\mathrm{HT}_{1}$ and $5-\mathrm{HT}_{7}$ receptors are considered to be relaxant and the $5-\mathrm{HT}_{2}, 5-\mathrm{HT}_{3}$ and $5-\mathrm{HT}_{4}$ receptors to be contractile (26-30).

The selective $5-\mathrm{HT}_{1 \mathrm{~A}}$ receptor agonists sumatriptan and buspirone have been identified to enhance esophageal peristalsis and LES function (31). Cohen et al (32) found that 5 -HT induced contractions mediated by the $5-\mathrm{HT}_{2}$ receptor in guinea pig and rabbit esophagus. In the present study, the presence of the 5- $\mathrm{HT}_{2}$ receptor in distal esophageal muscle and in the human LES was clearly identified. Among all 5-HT receptors, the 5- $\mathrm{HT}_{3}$ and $5-\mathrm{HT}_{4}$ receptors have been the most thoroughly studied in the gastrointestinal system. $5-\mathrm{HT}_{3}$ receptors mainly exist in the nervous system and gastrointestinal tract; the most well established physiological roles of the $5-\mathrm{HT}_{3}$ receptor are in the coordination of emesis and regulation of gastrointestinal motility (33). 5- $\mathrm{HT}_{3}$ receptor antagonists such as ondansetron and granisetron can mediate gastrointestinal contraction and intestinal secretion, and antagonize 5-HT-induced relaxation of the esophagus by increasing LES tone (34). The $5-\mathrm{HT}_{4}$ receptor-mediated response is predominant in the 5-HT-induced acceleration of motility associated with acetylcholine release in the gastrointestinal tract $(35,36)$, and previous studies have identified the $5-\mathrm{HT}_{4}$ receptor is localized on the myenteric plexus (37). The $5-\mathrm{HT}_{7}$ receptor was the last member of 5-HT receptor family to be discovered $(35,38)$. $5-\mathrm{HT}_{7}$ receptors have been implicated in the pathophysiology of several disorders; they play a role in smooth muscle relaxation within the vasculature and in the gastrointestinal tract $(39,40)$. Liu et al (41) identified the expression of four subtypes of 5-HT 7 receptor throughout the rat gastrointestinal tract. Yang et al (42) concluded that a 5-HT signaling pathway disorder may be a major factor in the pathogenesis of gastroesophageal reflux and reflux esophagitis in experiments on rats.

Through the use of RT-PCR and qPCR, the present study identified the mRNA of all seven 5-HT receptors in human LES sling fibers, clasp fibers, circular muscles of the esophageal body and gastric fundus. 5- $\mathrm{HT}_{3 \mathrm{~A}} \mathrm{R}$ and $5-\mathrm{HT}_{4} \mathrm{R}$ expression levels were the highest, followed by those of 5- $\mathrm{HT}_{1 \mathrm{~A}} \mathrm{R}$ and $5-\mathrm{HT}_{2 \mathrm{~A}} \mathrm{R}$; the lowest expression levels were found for $5-\mathrm{HT}_{5 \mathrm{~A}} \mathrm{R}, 5-\mathrm{HT}_{6} \mathrm{R}$ and $5-\mathrm{HT}_{7} \mathrm{R}$. Western blotting confirmed the expression of five of the 5-HT receptors, with the exception of $5-\mathrm{HT}_{5 \mathrm{~A}} \mathrm{R}$ and $5-\mathrm{HT}_{6} \mathrm{R}$. It is speculated that the low levels of $5-\mathrm{HT}_{5 \mathrm{~A}} \mathrm{R}$ and $5-\mathrm{HT}_{6} \mathrm{R}$ caused them to be undetectable. No significant difference in the extent of 5-HT receptor expression for each of the different receptor types was identified among the four types of muscle strip.

To the best of our knowledge, the present study is the first to identify 5 -HT receptor mRNA and protein expression in the human LES. Although little information concerning the physiological and pharmacological effects of 5-HT receptors on the LES is available, the detection of 5-HT receptors in the present study supports the notion that the serotonergic system is an important modulator of esophageal motility. In the future, the development of specific ligands, as well as the use of gene deletion animal models such as knock-out mice for each 5-HT receptor, should allow precise evaluation of the physiological and pharmacological effects of specific 5-HT receptors in the LES.

\section{Acknowledgements}

This study was funded by China Natural Science Foundation and Hebei Provincial Natural Science Foundation.

\section{References}

1. Hoyer D, Hannon JP and Martin GR: Molecular, pharmacological and functional diversity of 5-HT receptors. Pharmacol Biochem Behav 71: 533-554, 2002.

2. Beattie DT and Smith JA: Serotonin pharmacology in the gastrointestinal tract: a review. Naunyn-Schmiedebergs Arch Pharmacol 377: 181-203, 2008.

3. Li JP, Chang TM, Chey WY: Roles of 5-HT receptors in the release and action of secretin on pancreatic secretion in rats. Am J Physiol Gastrointest Liver Physiol 280: G595-602, 2001.

4. Martinucci I, de Bortoli N, Giacchino M, et al: Esophageal motility abnormalities in gastroesophageal reflux disease. World J Gastrointest Pharmacol Ther 5: 86-96, 2014.

5. Liu JF, Gao LP, Wen SW, et al: Responses of human sling and clasp fibers to cholecystokinin (CKK) and gastrin through CCK receptors. J Gastroenterol Hepatol 23: 1608-1612, 2008.

6. Liu JF, Lu HL, Wen SW and Wu RF: Effects of acetylcholine on sling and clasp fibers of the human lower esophageal sphincter. J Gastroenterol Hepatol 26: 1309-1317, 2011.

7. Livak KJ and Schmittgen TD: Analysis of relative gene expression data using real-time quantitative PCR and the 2 (-Delta Delta C(T)) method. Methods 25: 402-408, 2001.

8. Meneses A: 5-HT systems: emergent targets for memory formation and memory alterations. Rev Neurosci 24: 629-64, 2013.

9. Kato S: Role of serotonin 5-HT3 receptors in intestinal inflammation. Biol Pharm Bull 36: 1406-1409, 2013.

10. Hayes DJ, Greenshaw AJ: 5-HT receptors and reward-related behaviour: a review. Neurosci Biobehav Rev 35: 1419-1449, 2011.

11. Schneider JH, Küper MA, Königsrainer A and Brücher BL: Transient lower esophageal sphincter relaxation and esophageal motor response. J Surg Res 159: 714-719, 2010.

12. Gershon MD: Review article: serotonin receptors and transporters - roles in normal and abnormal gastrointestinal motility. Aliment Pharmacol Ther 20: 3-14, 2004.

13. Liu XB and Liu JF: Expression of dopamine receptors in human lower esophageal sphincter. J Gastroenterol Hepatol 27: 945-950, 2012.

14. Hansen MB and Jaffe BM: 5-HT receptor subtypes involved in luminal serotonin-induced secretion in rat intestine in vivo. J Surg Res 56: 277-287, 1994. 
15. Thompson AJ and Lummis SC: The 5-HT3 receptor as a therapeutic target. Expert Opin Ther Targets 11: 527-540, 2012.

16. Walstab J, Rappold G and Niesler B: 5-HT (3) receptors: role in disease and target of drugs. Pharmacol Ther 128: 146-169, 2010.

17. Mader R, Kocher T, Haier J, et al: Investigation of serotonin type 4 receptor expression in human and non-human primate gastrointestinal samples. Eur J Gastroenterol Hepatol 18: 945-950, 2006.

18. Champaneria S, Costall B, Naylor RJ and Robertson DW: Identification and distribution of 5-HT3 recognition sites in the rat gastrointestinal tract. Br J Pharmacol 106: 693-696, 1992

19. Irving HR, Tan YY, Tochon-Danguy N, et al: Comparison of 5-HT4 and 5-HT7 receptor expression and function in the circular muscle of the human colon. Life Sci 80: 1198-1205, 2007.

20. Wang GD, Wang XY, Zou F, et al: Mast cell expression of the serotonin $1 \mathrm{~A}$ receptor in guinea pig and human intestine. Am J Physiol Gastrointest Liver Physiol 304: G855-G863, 2013.

21. Waeber C, Grailhe R, Yu XJ, Hen R and Moskowitz MA: Putative 5-ht5 receptors: localization in the mouse CNS and lack of effect in the inhibition of dural protein extravasation. Ann NY Acad Sci 861: 85-90, 1998S.

22. Nelson DL: 5-HT5 receptors. Curr Drug Targets CNS Neurol Disord 3: 53-58, 2004.

23. Marazziti D, Baroni S, Catena Dell'Osso M, Bordi F and Borsini F: Serotonin receptors of type 6 (5-HT6): what can we expect from them? Curr Med Chem 18: 2783-2790, 2011.

24. Bonasera SJ, Chu HM, Brennan TJ and Tecott LH: A null mutation of the serotonin 6 receptor alters acute responses to ethanol. Neuropsychopharmacology 31: 1801-1813, 2006.

25. Chiu HJ, Wang YC, Liou JH, et al: Serotonin 6 receptor polymorphism in schizophrenia: frequency, age at onset and cognitive function. Neuropsychobiology 43: 113-116, 2001.

26. Janssen P, Prins NH, Moreaux B, et al: Characterization of 5-HT7-receptor-mediated gastric relaxation in conscious dogs. Am J Physiol Gastrointest Liver Physiol 289: 108-115, 2005.

27. Janssen P, Prins NH, Moreaux B, et al: In vivo characterization of 5-HT1A receptor-mediated gastric relaxation in conscious dogs. Br J Pharmacol 140: 913-920, 2003.

28. Janssen P, Prins NH, Meulemans AL, et al: Smooth muscle 5-HT2A receptors mediating contraction of porcine isolated proximal stomach strips. Br J Pharmacol 137: 1217-1224, 2002.

29. Prins NH, van der Grijn A, Lefebvre RA, et al: 5-HT(4) receptors mediating enhancement of contractility in canine stomach; an in vitro and in vivo study. Br J Pharmacol 132: 1941-1947, 2001.
30. Fox A and Morton IK: An examination of the 5-HT3 receptor mediating contraction and evoked $[3 \mathrm{H}]$-acetylcholine release in the guinea-pig ileum. Br J Pharmacol 101: 553-558, 1990.

31. Di Stefano M, Papathanasopoulos A, Blondeau K, et al: Effect of buspirone, a 5-HT1A receptor agonist, on esophageal motility in healthy volunteers. Dis Esophagus 25: 470-476, 2012.

32. Cohen ML, Susemichel AD, Bloomquist W and Robertson DW: 5-HT4 receptors in rat but not guinea pig, rabbit or dog esophageal smooth muscle. Gen Pharmacol 25: 1143-1148, 1994.

33. Machu TK: Therapeutics of 5-HT3 receptor antagonists: current uses and future directions. Pharmacol Ther 130: 338-347, 2011.

34. Miyata K, Yamano M, Kamato T and Akuzawa S: Effect of serotonin (5-HT)3-receptor antagonists YM060, YM114 (KAE393 ), ondansetron and granisetron on 5-HT4 receptors and gastric emptying in rodents. Jpn J Pharmacol 69: 205-214, 1995.

35. Poole DP, Xu B, Koh SL, et al: Identification of neurons that express 5-hydroxytryptamine 4 receptors in intestine. Cell Tissue Res 325: 413-422, 2006.

36. Saegusa Y, Takeda H, Muto S, et al: Decreased motility of the lower esophageal sphincter in a rat model of gastroesophageal reflux disease may be mediated by reductions of serotonin and acetylcholine signaling. Biol Pharm Bull 34: 704-711, 2011.

37. Ren J, Zhou X and Galligan JJ: 5-HT4 receptor activation facilitates recovery from synaptic rundown and increases transmitter release from single varicosities of myenteric neurons. Am J Physiol Gastrointest Liver Physiol 294: G1376-1383, 2008.

38. Taniyama K, Kaibara M, Uezono Y and Hayashi H: Functional difference of prokinetics depending on subtypes and localization of receptor in alimentary tract. Nihon Yakurigaku Zasshi 122 (Suppl): 63PP-66PP, 2003 (In Japanese).

39. Vanhoenacker P, Haegeman G and Leysen JE: 5-HT7 receptors: current knowledge and future prospects. Trends Pharmacol Sci 21: 70-77, 2000.

40. Tonini M, Vicini R, Cervio E, et al: 5-HT7 receptors modulate peristalsis and accommodation in the guinea pig ileum. Gastroenterology 129: 1557-1566, 2005.

41. Liu H, Irving HR and Coupar IM: Expression patterns of 5-HT7 receptor isoforms in the rat digestive tract. Life Sci 69: 24672475,2001

42. Yang L, Cai H, Tou J, et al: The role of the 5-hydroxytryptamine pathway in reflux-induced esophageal mucosal injury in rats. World J Surg Oncol 10: 219, 2012. 